\title{
Hydroxychloroquine treatment for primary Sjögren's syndrome: a two year double blind crossover trial.
}

A A Kruize, R J Hené, C G M Kallenberg, O P van Bijsterveld, A van der Heide, L Kater, J W J Bijlsma

\begin{abstract}
Objectives-In 1985 and 1988 a positive effect of treatment of primary Sjögren's syndrome with hydroxychloroquine was reported in two small open studies. To investigate further the clinical and laboratory effects of hydroxychloroquine in primary Sjögren's syndrome a two year study was performed.
\end{abstract}

Methods-The design of the study included a prospective, placebo controlled, two year double blind crossover trial in 19 patients

Results-A significant decrease in IgG and $I g M$ and a tendency for a decrease in the erythrocyte sedimentation rate (ESR) during treatment with hydroxychloroquine compared with treatment with placebo were found. No beneficial clinical effect of the use of hydroxychloroquine as expressed in preference for treatment with hydroxychloroquine or placebo with regard to symptoms and signs of primary Sjögren's syndrome could be shown, however, nor any relevant change in tear gland activity and sequelae of peripheral tear function deficiency, nor salivary gland scintigraphy.

Conclusions-The use of hydroxychloroquine at a dose of $400 \mathrm{mg}$ daily taken over a 12 month period does not have a worthwhile clinical benefit in patients with primary Sjögren's syndrome despite an improvement of hyperglobulinaemia and slight changes in the ESR and IgM.

(Ann Rheum Dis 1993; 52: 360-364)

Primary Sjögren's syndrome is a systemic disease characterised by dryness of the eyes and mouth due to lymphocytic infiltration of the lachrymal and salivary glands. ${ }^{1-3}$ Extraglandular manifestations are not uncommon. ${ }^{145}$ The aetiology and pathogenesis are not known. Because of the generally benign character of the disease primary Sjögren's syndrome is preferably managed by symptomatic measures only. If myalgia and arthralgia are present, analgesics and nonsteroidal anti-inflammatory drugs (NSAIDs) can be used. Low dose corticosteroids may be beneficial when systemic features such as invalidating weariness occur, but high dose corticosteroids are indicated only in cases of life threatening extraglandular manifestations. Cytotoxic drugs are contraindicated because of a possible enhancement of the already excess risk of the development of lymphoma in primary Sjögren's syndrome. ${ }^{6}$

In several rheumatic diseases, such as rheumatoid arthritis and systemic lupus erythematosus, hydroxychloroquine has a therapeutically beneficial effect. ${ }^{7-10}$ The mechanism of action of hydroxychloroquine in these rheumatic diseases is not fully understood. It has been suggested that it is caused by interference with macrophage processing of antigens, resulting in an interaction with $\mathrm{T}$ cell activation. ${ }^{11}{ }^{12}$ As $\mathrm{T}$ cell derived lymphokines are required for $\mathrm{B}$ cells to switch from $\operatorname{IgM}$ to IgG synthesis, treatment with hydroxychloroquine in patients with Sjögren's syndrome could lead to a decrease in their IgG hyperglobulinaemia. ${ }^{12}$ In 1985 a positive effect of treatment of primary Sjögren's syndrome with hydroxychloroquine was found in a small open study with three patients lasting for nine, 20, and 59 months, respectively. ${ }^{13}$ All three patients reported a subjective improvement in disorders of the eyes and mouth. Laboratory data showed a decrease of the erythrocyte sedimentation rate (ESR) and the $\gamma$ globulin serum levels, in combination with an increase of serum haemoglobin concentration. In 1988 the potential benefit of hydroxychloroquine was evaluated in an open comparative study including 20 patients with primary Sjögren's syndrome, matched for age and sex. ${ }^{12}$ The group of 10 patients treated with hydroxychloroquine showed a significantly larger decrease in total IgG and the ESR and an increase in haemoglobin compared with the group of 10 patients treated with placebo. Subjective clinical effects were not reported. In 1987 we started a prospective, placebo controlled, crossover double blind trial to investigate further the clinical and laboratory effects of hydroxychloroquine in patients with primary Sjögren's syndrome.

\section{Patients and methods}

Nineteen patients with primary Sjögren's syndrome defined according to the criteria proposed by Daniels and Talal $^{3}$ in 1987 (table 1) were included in the study. Twelve patients were seen at the University Hospital Utrecht and seven at the University Hospital Groningen, The Netherlands. The mean (SD) 
Table 1 Diagnostic criteria for primary Sjögren's syndrome proposed by Daniels and Talal $(1987)^{3}$

1 Keratoconjunctivitis sicca
a Characteristic corneal and conjunctival epithelial staining with rose bengal observed
through a slit lamp; and
b reduced tear meniscus and breakup time; or
c unanaesthetised Schirmer's test $<5 \mathrm{~mm} /$ five minutes
2 Focal sialadenitis in an adequate labial salivary gland biopsy specimen with a focus score
greater than one focus $/ 4 \mathrm{~mm}^{2}$ after exclusions

age was $51.9(15 \cdot 5)$ years, the median (range) disease duration was $3 \cdot 0(0 \cdot 1-23 \cdot 0)$ years; disease duration was measured from the time of confirmation of the clinical diagnosis by a salivary gland biopsy sample. Exclusion criteria for the study included treatment with hydroxychloroquine, corticosteroids, or immunosuppressive drugs in the three months preceding the start of the study; ophthalmological contraindications for the use of hydroxychloroquine, such as retinitis pigmentosa; and other concurrent systemic rheumatic disease such as rheumatoid arthritis, systemic lupus erythematosus, systemic sclerosis, and mixed connective tissue disease.

The study was approved by the ethical committees of the two hospitals. After informed consent patients were randomised (in blocks of four) to one of two treatment groups. The first group was treated with hydroxychloroquine for one year and with placebo during the second year. In the second group treatment was given in the reverse order. Hydroxychloroquine dosage was $400 \mathrm{mg}$ daily, given in two tablets of $200 \mathrm{mg}$ each. Placebo tablets, indistinguishable from hydroxychloroquine tablets, were also given twice daily. Previously applied symptomatic treatment was continued in all patients.

Every three months parameters of efficacy were determined (by RJH, JWJB, and CGMK). (a) In a standard questionnaire patients were asked for the presence and severity compared with the previous visit of the following symptoms: dryness or a sandy feeling of the eyes, infection of the eyes or the eyelids, dryness of the mouth, swelling of the salivary glands, fatigue, myalgia, and arthralgia. (b) Patients were physically examined for signs of swelling of the parotid and submandibular salivary glands, lymphadenopathy, and hepatosplenomegaly. (c) Biochemical parameters included ESR (Westergren), and serum levels of haemoglobin, total protein, albumin, $\alpha_{1}, \alpha_{2}$, $\beta$, and $\gamma$ globulins. (d) Immunoserological parameters included serum levels of IgG, IgM, and IgA, as well as qualitative tests for rheumatoid factor, antinuclear antibodies, and antibodies to double stranded DNA, SSA, and SSB.

For patients seen at the University Hospital of Utrecht tear gland function was evaluated with tests measuring tear gland activity (tear lysozyme concentration, tear lactoferrin concentration, and Schirmer's test) and tests measuring the sequelae of peripheral tear function deficiency (break up time and rose bengal test), performed as described by van Bijsterveld and coworkers. ${ }^{14} 15$ These patients also had salivary gland scintigraphy using technetium-99m, including a recording of the accumulation and secretion of radioactive labelled pertechnetate by the salivary glands, and gallium-67 citrate showing an increased uptake of gallium citrate if a cellular reactive process was present, possibly through lactoferrin as a gallium citrate binding protein in polymorphonuclear leucocytes. ${ }^{16}$ Technetium99m scintigraphy (Tc scan) therefore represents the function of the major salivary glands, whereas gallium-67 citrate scintigraphy (Ga scan) indicates the activity of inflammation of the salivary glands. Quantification of salivary scintigraphy is difficult because of the anatomical site and shape of the glands, so all scans were scored blindly by an independent observer and two of the authors (AAK and $\mathrm{RJH}$ ).

Safety and tolerability assessments included whole blood count, serum creatinine, alkaline phosphatase, and transaminases every three months; ophthalmological examination was performed before the study, after one year, and after two years; if retinal changes were present the examination was repeated every three months.

\section{STATISTICS}

The effects of treatment with hydroxychloroquine and placebo in the two groups were analysed by comparing differences in outcome after the first and the second year between the two groups for continuous variables; only the results at the end of the two years were analysed because of possible carryover effects at earlier phases in a year. ${ }^{17}$ Differences were tested for statistical significance using Student's $t$ tests and the Wilcoxon rank sum tests because of the small size of the study. As the results were similar, only the results of the $t$ tests are reported here. For binary variables obtained from the questionnaire on clinical symptoms, the overall preference of patients for one of the two treatment periods was used to compare groups. ${ }^{18}$ Fisher's exact test was used to assess statistical significance. p Values of less than 0.05 were considered significant in all analyses.

\section{Results}

Nineteen patients, all women, took part in the study. Group $\mathrm{HC} \rightarrow$ plac, in which patients were treated with hydroxychloroquine in the first year and with placebo in the second year, consisted of 10 patients. Group plac $\rightarrow \mathrm{HC}$, in which the order of treatment was reversed, consisted of nine patients.

In group $\mathrm{HC} \rightarrow$ plac the mean (SD) age was $52 \cdot 8(16 \cdot 1)$ years; in group plac $\rightarrow \mathrm{HC}$ it was $51 \cdot 0(15 \cdot 8)$ years. Median (range) disease duration in group $\mathrm{HC} \rightarrow$ plac was $2 \cdot 5(0 \cdot 1-15 \cdot 0)$ years and in group plac $\rightarrow$ HC $5 \cdot 0(0 \cdot 6-23 \cdot 0)$ years (table 2). Drugs used at the start of the trial are shown in table 3; these drugs were not changed during the course of the study.

Four patients did not complete the study, two in each group. In group $\mathrm{HC} \rightarrow$ plac one patient received corticosteroids because of pro- 
Table 2 Characteristics of patients at entry

\begin{tabular}{lcc}
\hline $\begin{array}{l}\text { Patient } \\
\text { characteristics }\end{array}$ & $\begin{array}{l}H C \rightarrow \text { plac } \\
(n=10)\end{array}$ & $\begin{array}{c}\text { plac } \rightarrow H C^{\star} \\
(\mathrm{n}=9)\end{array}$ \\
\hline No of women & 10 & 9 \\
Utrecht Hospital & 6 & 6 \\
Groningen Hospital & 4 & 3 \\
Mean (SD) age (years) & $52 \cdot 8(16 \cdot 1)$ & $51 \cdot 0(15 \cdot 8)$ \\
Median (range) duration of disease (years) & $2 \cdot 5(0 \cdot 1-15 \cdot 0)$ & $5 \cdot 0(0 \cdot 6-23 \cdot 0)$ \\
\hline
\end{tabular}

${ }^{\star} \mathrm{HC} \rightarrow$ plac $=$ first year hydroxychloroquine, second year placebo; plac $\rightarrow \mathrm{HC}=$ first year placebo, second year hydroxychloroquine.

Table 3 Drug treatment at entry

\begin{tabular}{lll}
\hline Drug & Indication & No of patients \\
\hline Tear substitutes & Dry eyes & 10 \\
Saliva substitutes & Xerostomia & 2 \\
Paracetamol/NSAIDs* & Myalgia/arthralgia & 4 \\
Sedatives & Insomnia & 6 \\
Anti-hypertensive drugs & Cardiovascular disease & 4 \\
Anti-convulsant drugs & Epilepsy & 2 \\
L-Thyroxine & Hypothyroidism & 2 \\
Insulin & Diabetes mellitus & 1 \\
Calcium carbonate & Osteoporosis & 3 \\
Lactulose & Obstipation & 3 \\
\hline
\end{tabular}

^NSAIDs=non-steroidal anti-inflammatory drugs.

gressive peripheral neuropathy three months after the start of the study while using hydroxychloroquine, and another patient was admitted to hospital 16 months after the start of the study because of massive pleural effusion while using placebo; she died within one month from what appeared to be Burkitt's lymphoma. In group plac $\rightarrow \mathrm{HC}$ one patient received corticosteroids because of progressive peripheral neuropathy 12 months after the start of the study while using placebo; another patient withdrew herself from the study 10 months after the start while using placebo because of psychological reasons not related to the study. Finally, one patient, who completed the study, was excluded afterwards because of lack of compliance. Analysis was thus performed on eight patients in group $\mathrm{HC} \rightarrow$ plac and six patients in group plac $\rightarrow$ HC. No difference between the two groups in clinical and laboratory features was found at the start of the study.

CLINICAL SYMPTOMS

Patients expressed no clear preference for treatment with hydroxychloroquine or placebo

Table 4 Clinical symptoms. No significant differences were found (Fisher's exact test)

\begin{tabular}{|c|c|c|c|c|}
\hline $\begin{array}{l}\text { Clinical } \\
\text { symptoms }\end{array}$ & $\begin{array}{l}\text { Treatment } \\
\text { order }^{\star}\end{array}$ & $\begin{array}{l}\text { Preference } \\
\text { first yeart }\end{array}$ & $\begin{array}{l}\text { Preference } \\
\text { second yeart }\end{array}$ & No preferencet \\
\hline Dry eyes & $\begin{array}{l}\mathrm{HC} \rightarrow \text { plac }(7 / 8) \\
\text { plac } \rightarrow \text { HC }(6 / 6)\end{array}$ & $\begin{array}{l}4 \\
2\end{array}$ & $\begin{array}{l}0 \\
0\end{array}$ & $\begin{array}{l}4 \\
4\end{array}$ \\
\hline Sandy feeling in eyes & $\begin{array}{l}\mathrm{HC} \rightarrow \text { plac }(4 / 8) \\
\text { plac } \rightarrow \text { HC }(5 / 6)\end{array}$ & $\begin{array}{l}2 \\
2\end{array}$ & $\begin{array}{l}0 \\
0\end{array}$ & $\begin{array}{l}6 \\
4\end{array}$ \\
\hline Infection of eyes & $\begin{array}{l}\mathrm{HC} \rightarrow \text { plac }(1 / 8) \\
\text { plac } \rightarrow \text { HC }(3 / 6)\end{array}$ & $\begin{array}{l}2 \\
1\end{array}$ & $\begin{array}{l}0 \\
0\end{array}$ & $\begin{array}{l}6 \\
5\end{array}$ \\
\hline Dry mouth & $\begin{array}{l}\mathrm{HC} \rightarrow \text { plac }(6 / 8) \\
\text { plac } \rightarrow \text { HC }(6 / 6)\end{array}$ & $\begin{array}{l}4 \\
3\end{array}$ & $\begin{array}{l}0 \\
1 \\
0\end{array}$ & $\begin{array}{l}3 \\
3\end{array}$ \\
\hline Parotid swelling & $\begin{array}{l}\mathrm{HC} \rightarrow \text { plac }(6 / 8) \\
\text { plac } \rightarrow \text { HC }(3 / 6)\end{array}$ & $\begin{array}{l}4 \\
1\end{array}$ & $\begin{array}{l}2 \\
1\end{array}$ & $\begin{array}{l}2 \\
4\end{array}$ \\
\hline Fatigue & $\begin{array}{l}\mathrm{HC} \rightarrow \text { plac }(6 / 8) \\
\text { plac } \rightarrow \text { HC }(6 / 6)\end{array}$ & 2 & 2 & $\begin{array}{l}4 \\
3\end{array}$ \\
\hline Myalgia & $\begin{array}{l}\mathrm{HC} \rightarrow \text { plac }(1 / 8) \\
\text { plac } \rightarrow \text { HC }(5 / 6)\end{array}$ & $\begin{array}{l}0 \\
0\end{array}$ & $\begin{array}{l}1 \\
0\end{array}$ & $\begin{array}{l}7 \\
6\end{array}$ \\
\hline Arthralgia & $\begin{array}{l}\mathrm{HC} \rightarrow \text { plac }(2 / 8) \\
\text { plac } \rightarrow \text { HC }(4 / 6)\end{array}$ & $\begin{array}{l}1 \\
3\end{array}$ & $\begin{array}{l}0 \\
0\end{array}$ & $\begin{array}{l}7 \\
3\end{array}$ \\
\hline
\end{tabular}

${ }^{\star} \mathrm{HC} \rightarrow$ plac $=$ first year hydroxychloroquine, second year placebo; plac $\rightarrow \mathrm{HC}=$ first year placebo, second year hydroxychloroquine; $\left({ }^{\star} /\right)^{*}=$ number of patients suffering from this symptom at entry

number of patients in this group. year=number of patients who preferred second year period; no preference=number of patients who did not prefer either period, or who did not have disorder. with respect to symptoms of dryness or sandy feelings of the eyes, inflammatory reaction of the eyes or eyelids, or symptoms of dryness of the mouth. No statistically significant differences were found for swelling of the salivary glands, fatigue, myalgia, nor arthralgia (table 4). No significant period effect nor interaction between treatment and period was found for any of the outcome measures, although patients in the two groups tended to prefer the drug they used in the first year of the study.

\section{IMMUNOSEROLOGY}

Hydroxychloroquine and placebo treatment did not result in statistically significant differences for most of the laboratory parameters, except for $\gamma$ globulin $(p<0.05)$, IgM $(\mathrm{p}<0.005)$, and IgG ( $\mathrm{p}<0.05)$ (table 5). Serum levels of these latter parameters were lower after treatment with hydroxychloroquine. The ESR was lower after treatment with hydroxychloroquine; the difference was, however, not statistically significant $(p=0 \cdot 07)$. No change was seen in the qualitative tests for rheumatoid factor (in seven of the 14 patients rheumatoid factor was positive at entry and at the end of the study), antinuclear antibodies (7/14), nor in antibodies to double stranded DNA (0/14), SSA (10/14), and SSB (7/14).

A period effect was found for the outcome measures $\operatorname{ESR}(p<0.05)$ and $\operatorname{IgM}(p<0.05)$, which decreased during the course of the study.

No statistically significant interaction between treatment and period could be detected for any of the laboratory outcome measures.

\section{TEAR GLAND FUNCTION}

No significant difference was found in tear gland activity nor in the sequelae of peripheral tear function deficiency (table 6). No period effect or interaction effect between treatment and period was found for any of the tear gland function parameters.

\section{SALIVARY SCINTIGRAPHY}

In nine patients no major change was noticed in Tc nor Ga scintigraphy compared with initial scintigraphy. In one patient, however, increased activity on the initial $\mathrm{Ga}$ scan had not changed after the first year in which the patient was treated with placebo, but disappeared after the second year in which patient was treated with hydroxychloroquine, resulting in a normal Ga scan. A clinical decrease in swelling of the parotid glands was noticed in this patient. No change was seen in the Tc scan of this patient (table 7).

\section{SIDE EFFECTS}

One patient developed a moderate deterioration of liver function tests at the end of the first year in which she appeared to have been treated with hydroxychloroquine. Alkaline phosphatase increased from 72 to 179 (normal 
Table 5 Laboratory outcome measures

\begin{tabular}{|c|c|c|c|c|c|c|}
\hline $\begin{array}{l}\text { Laboratory } \\
\text { measure }\end{array}$ & $\begin{array}{l}\text { Treatment } \\
\text { order } \\
\text { (no of patients) }\end{array}$ & At entry & $\begin{array}{l}\text { After } \\
\text { one year }\end{array}$ & $\begin{array}{l}\text { After } \\
\text { two years }\end{array}$ & $\stackrel{\sigma}{H C \text {-plac }}$ & $\stackrel{p}{\text { Valuef }}$ \\
\hline \multirow[t]{2}{*}{ ESR† (mm/1st hour) } & $\mathrm{HC} \rightarrow$ plac (8) & $37 \cdot 8(9 \cdot 8)$ & $27.5(19 \cdot 8)$ & $37 \cdot 5(25 \cdot 3)$ & $-10 \cdot 0(7 \cdot 2)$ & \multirow[b]{2}{*}{ NS } \\
\hline & plac $\rightarrow$ HC (6) & $27 \cdot 1(14 \cdot 9)$ & $26 \cdot 2(29 \cdot 4)$ & $26 \cdot 7(32 \cdot 2)$ & $0.5(9 \cdot 6)$ & \\
\hline $\operatorname{IgA}(g / 1)$ & $\begin{array}{l}\mathrm{HC} \rightarrow \text { plac }(8) \\
\text { plac } \rightarrow \text { HC (6) }\end{array}$ & $\begin{array}{l}3 \cdot 7(0 \cdot 6) \\
2 \cdot 8(0 \cdot 9)\end{array}$ & $\begin{array}{l}3 \cdot 8(1 \cdot 9) \\
3 \cdot 0(2 \cdot 2)\end{array}$ & $\begin{array}{l}4 \cdot 1(1 \cdot 7) \\
3 \cdot 0(2 \cdot 5)\end{array}$ & $\begin{array}{r}-0 \cdot 3(0 \cdot 2) \\
0 \cdot 0(0 \cdot 3)\end{array}$ & NS \\
\hline \multirow[t]{2}{*}{$\operatorname{IgM}(\mathrm{g} / \mathrm{l})$} & $\mathrm{HC} \rightarrow$ plac (8) & $2 \cdot 5(0 \cdot 4)$ & $1 \cdot 7(1.0)$ & $2 \cdot 3(1 \cdot 5)$ & $-0.5(0.6)$ & \multirow[b]{2}{*}{0.02} \\
\hline & plac $\rightarrow$ HC $(6)$ & $2 \cdot 2(0 \cdot 6)$ & $2 \cdot 0(1 \cdot 1)$ & $1.9(1.2)$ & $-0 \cdot 1(0 \cdot 2)$ & \\
\hline \multirow[t]{2}{*}{$\operatorname{IgG}(g / 1)$} & $\mathrm{HC} \rightarrow$ plac $(8)$ & $24 \cdot 1(3 \cdot 0)$ & $19 \cdot 9(7 \cdot 2)$ & $22.5(8.9)$ & $-2 \cdot 6(3 \cdot 8)$ & \\
\hline & plac $\rightarrow$ HC (6) & $16 \cdot 7(4 \cdot 1)$ & $16 \cdot 6(9 \cdot 8)$ & $15 \cdot 1(8 \cdot 0)$ & $-1.5(1.9)$ & 0.02 \\
\hline
\end{tabular}

${ }^{\star} \mathrm{HC} \rightarrow$ plac $=$ first year hydroxychloroquine, second year placebo; plac $\rightarrow \mathrm{HC}=$ first year placebo, second year hydroxychloroquine. †ESR=erythrocyte sedimentation rate $(\mathrm{mm})$

łStudent's $t$ test.

Table 6 Tear gland function

\begin{tabular}{|c|c|c|c|c|c|c|}
\hline Tear gland function & $\begin{array}{l}\text { Treatment } \\
\text { order } \\
(n=5)\end{array}$ & At entry & $\begin{array}{l}\text { After } \\
\text { one year }\end{array}$ & $\begin{array}{l}\text { After } \\
\text { two years }\end{array}$ & $\begin{array}{l}\sigma \\
H C-p l a c\end{array}$ & $\stackrel{p}{\text { Valuet }}$ \\
\hline Tear lysozyme concentration $(\mu \mathrm{g} / \mathrm{ml})$ & $\begin{array}{l}\mathrm{HC} \rightarrow \text { plac } \\
\text { plac } \rightarrow \mathrm{HC}\end{array}$ & $\begin{array}{l}1555(1362) \\
1145(557)\end{array}$ & $\begin{array}{l}1630(1217) \\
1345(694)\end{array}$ & $\begin{array}{l}1590(1170) \\
1320(368)\end{array}$ & $\begin{array}{r}40(601) \\
-25(386)\end{array}$ & NS \\
\hline Tear lactoferrin concentration (mm precipitation) & $\begin{array}{l}\mathrm{HC} \rightarrow \text { plac } \\
\text { plac } \rightarrow \text { HC }\end{array}$ & $\begin{array}{l}8 \cdot 1(4 \cdot 2) \\
6 \cdot 3(3 \cdot 3)\end{array}$ & $\begin{array}{l}8 \cdot 7(3 \cdot 4) \\
8 \cdot 4(2 \cdot 3)\end{array}$ & $\begin{array}{r}10 \cdot 7(7 \cdot 1) \\
7 \cdot 2(2 \cdot 4)\end{array}$ & $\begin{array}{l}-2 \cdot 0(4 \cdot 5) \\
-1 \cdot 2(0 \cdot 8)\end{array}$ & NS \\
\hline Schirmer's test (mm/five minutes) & $\begin{array}{l}\mathrm{HC} \rightarrow \text { plac } \\
\text { plac } \rightarrow \mathrm{HC}\end{array}$ & $\begin{array}{l}8 \cdot 4(9 \cdot 4) \\
7 \cdot 8(4 \cdot 6)\end{array}$ & $\begin{array}{l}6 \cdot 8(9 \cdot 3) \\
8 \cdot 1(8 \cdot 8)\end{array}$ & $\begin{array}{l}8 \cdot 9(9 \cdot 0) \\
7 \cdot 0(6 \cdot 9)\end{array}$ & $\begin{array}{l}-2 \cdot 1(3 \cdot 4) \\
-1 \cdot 1(2 \cdot 2)\end{array}$ & NS \\
\hline Break up time (s) & $\mathrm{HC} \rightarrow$ plac & $1.9(0.9)$ & $2 \cdot 6(2 \cdot 3)$ & $2 \cdot 5(2 \cdot 1)$ & $0 \cdot 1(0.7)$ & \\
\hline Rose bengal test (score $0-9$ ) & $\begin{array}{l}\text { plac } \rightarrow \text { HC } \\
\mathrm{HC} \rightarrow \text { plac } \\
\text { plac } \rightarrow \text { HC }\end{array}$ & $\begin{array}{l}4 \cdot 8(6 \cdot 9) \\
3 \cdot 7(1 \cdot 6) \\
3 \cdot 9(1 \cdot 8)\end{array}$ & $\begin{array}{l}3 \cdot 5(3 \cdot 4) \\
5 \cdot 7(2 \cdot 8) \\
5 \cdot 4(1 \cdot 9)\end{array}$ & $\begin{array}{l}1 \cdot 5(0 \cdot 6) \\
5 \cdot 7(1 \cdot 9) \\
6 \cdot 1(1.9)\end{array}$ & $\begin{array}{r}-2 \cdot 0(3 \cdot 4) \\
0.0(1 \cdot 5) \\
0 \cdot 7(1 \cdot 1)\end{array}$ & $\begin{array}{l}\text { NS } \\
\text { NS }\end{array}$ \\
\hline
\end{tabular}

${ }^{\star} \mathrm{HC} \rightarrow$ plac $=$ first year hydroxychloroquine, second year placebo; plac $\rightarrow \mathrm{HC}=$ first year placebo, second year hydroxychloroquine. †Student's $t$ test.

Table 7 Salivary scintigraphy

\begin{tabular}{llllll}
\hline $\begin{array}{l}\text { Salivary } \\
\text { scintigraphy* }\end{array}$ & $\begin{array}{l}\text { Treatment } \\
\text { ordert } \\
(n=5)\end{array}$ & $\begin{array}{l}\text { At entry } \\
\text { (no of patients) }\end{array}$ & $\begin{array}{l}\text { After } \\
\text { one year }\end{array}$ & $\begin{array}{l}\text { After } \\
\text { two years }\end{array}$ & $\begin{array}{l}\text { O } \\
\text { HC-plac }\end{array}$ \\
\hline Tc & HC $\rightarrow$ plac & Abnormal(4) & 4 & 4 & 0 \\
& plac $\rightarrow$ HC & Normal(1) & 1 & 1 & 0 \\
& Abnormal(3) & 3 & 3 & 0 \\
Ga & Normal(2) & 2 & 2 & 0 \\
& HC $\rightarrow$ plac & Abnormal (4) & 4 & 4 & 0 \\
& plac $\rightarrow$ HC & Aormal(1) & 1 & 1 & 1 \\
& & Abnormal(4) & 4 & 3 & 1 \\
\hline
\end{tabular}

${ }^{\star} \mathrm{T} \mathrm{c}=\mathrm{Technetium}-99 \mathrm{~m}$ pertechnetate salivary scintigraphy; $\mathrm{Ga}=\mathrm{Gallium}-67$ citrate salivary

$\dagger \mathrm{HC} \rightarrow$ plac $=$ first year hydroxychloroquine, second year placebo; $\mathrm{plac} \rightarrow \mathrm{HC}=$ first year placebo, second year hydroxychloroquine.

27-93) IU/l, serum $\gamma$-glutamyltransferase from 6 to 87 (normal 7-29) IU/l, serum aspartate transaminase from 19 to 45 (normal <30) IU/l, serum alanine transaminase from 11 to 67 (normal <30) IU/l, whereas serum lactate dehydrogenase remained within the normal range. An expectative policy was followed. Liver function tests normalised within two months after cross over. No other side effect was noticed.

\section{Discussion}

No clinical beneficial effect of the use of hydroxychloroquine in the treatment of primary Sjögren's syndrome was found in this study as expressed in the patient's preference for treatment with hydroxychloroquine or placebo, tear gland activity and sequelae of peripheral tear function deficiency, and salivary gland scintigraphy. Nevertheless we showed a decrease in IgG and IgM during treatment with hydroxychloroquine compared with treatment with placebo. Our results partly confirm those published by Fox et al. ${ }^{12}$ In contrast with these workers we did not find any differences in serum haemoglobin concentra- tion and immunoglobulin A. Although a decrease in ESR during treatment with hydroxychloroquine occurred, statistical significance was not found when comparing the values of ESR at the end of both years. It has been suggested that hydroxychloroquine is particularly effective in patients with an increased ESR and raised immunoglobulin levels. ${ }^{12}$ Our patients obviously had active disease with many disorders (as expressed in table 3) at entry and laboratory parameters at entry were also compatible with active disease.

The possibility that a higher dose of hydroxychloroquine, which might be more harmful to the retina, or prolonged treatment with hydroxychloroquine might have a more beneficial effect cannot be ruled out on the basis of the current study.

Primary Sjögren's syndrome is an insidious disease leading to destruction of glandular tissue. Whereas the aim of treatment is to decrease the inflammatory activity of the disease which might improve the overall wellbeing of the patient, the already damaged exocrine gland tissue is not likely to be restored. Unfortunately in our study even a decrease of the local glandular inflammatory activity, measured by Ga scan, is not seen. We conclude that the use of hydroxychloroquine in a dose of $400 \mathrm{mg}$ daily taken over a 12 month period does not have a clinical beneficial effect in patients with primary Sjögren's syndrome in spite of an improvement of hyperglobulinaemia and slight changes in the ESR and IgM.

We thank Dr H J A Wijnne for his generous advice in statistical analysis, Dr P P van Rijk for scoring salivary scintigraphies, Dr A F A M Schobben, pharmacologist, for randomisation, and Winthrop pharmaceutical industry for kind supply of the tria drugs. This paper is dedicated to the memory of Mrs Mieke Snellenberg, who enthusiastically took care of the logistic terms that made the study possible. 
1 Talal N, Moutsopoulos H M, Kassan S S, eds. Sjögren's syndrome, clinical and immunological aspects. Berlin: Springer Verlag, 1987.

2 Fox R I, Robinson C A, Curd J G, Kozin F, Howell F V. Sjögren's syndrome, proposed criteria for classification. Arthritis Rheum 1987; 29: 577-85.

3 Daniels T E Talal N. Diagnosis and differential diagnosis of Siögren's syndrome. In: Talal N, Moutsopoulos H M Kassan S S, eds. Sjögren's syndrome, clinical an Kassan S S, eds. Sjögren's syndrome, clinical

4 Hené R J, Kruize A A, Bijlsma J W J, Kater L. Morbus Sjögren, more than a dry syndrome. Neth $\mathcal{F}$ Med 1992; 40 $108-12$.

5 Kruize A A, Hené R J, Oey P J, Kater L, Bijlsma J W J Neuro-musculo-skeletal manifestations in primary Sjögren's syndrome. Neth f Med 1992; 40: 135-9.

6 Kassan S S, Thomas T L, Moutsopoulos H M, et al. Increased risk of lymphoma in sicca syndrome. Ann Inter Med 1978; 89: 888-92.

7 Esdaile J, et al, The Canadian Hydroxychloroquine Study Group. A randomized study of the effect of withdrawin hydroxychloroquine sulfate in systemic lupus erythematosus. $N$ Engl 7 Med 1991; 324: 150-4

8 Runge L A. Risk/benefit analysis of hydroxychloroquine sulfate treatment in rheumatoid arthritis. Am f Med 1983; 75: $52-7$.
9 Klinefelter H F, Achurra A. Effect of gold salts and antimalarials on the rheumatoid factor in rheumatoid arthritis. Scand $\mathcal{F}$ Rheumatol 1973; 2: 177-82.

10 Freedman A, Steinberg V L. Chloroquine in rheumatoid arthritis, a double blindfold trial of treatment for one year. Ann Rheum Dis 1960; 19: 243-50.

11 Grey $\mathrm{H}$ M, Chesnut R. Antigen processing and presentation to T-cells. Immunol Today 1985; 6: 101-2.

12 Fox R I, Chan E, Benton L, Fong S, Friedlaender M Howell F V. Treatment of primary Sjögren's syndrome with hydroxychloroquine. Am $\mathcal{F}$ Med 1988; 85(suppl 4A): $62-7$.

13 Lakhanpal S, Duffy J, Griffing W L, Conn D L, Luthra H S. Sjögren's syndrome: treatment with D-penicillamin and hydroxychloroquine. F Rheumatol 1985; 12: 1028-9.

14 Van Bijsterveld O P. Diagnostic tests in the sicca syndrome. Arch Ophthalmol 1969; 82: 10-4.

15 Klaassen-Broekema N, Mackor A J, van Bijsterveld O P. The diagnostic power of the tests for tear gland related The diagnostic power of the tests for tear gland related

16 Mishkin F S. Radionuclide salivary gland imaging. Semin Nucl Med 1981; 11: 258-65.

17 Pocock S J. Cross-over trials. Clinical trials, a practical approach. Chichester: Wiley, 1983.

18 Hills M, Armitage P. The two-period cross-over clinical trial. Br f Clin Pharmacol 1979; 8: 7-20.

ב

